\title{
Proposed Relationships between Trust of Business Social Responsibility (BSR) and Firms Performance in Nigeria.
}

\author{
${ }^{1}$ Haim Hilman, ${ }^{2}$ Abdullahi Hassan Gorondutse \\ ${ }^{1}$ Universiti Utara Malaysia \\ ${ }^{2}$ Phd (Candidate) School of Business management, College of Business, Universiti Utara Malaysia
}

\begin{abstract}
In the context of Nigeria, the issue of Business social responsibility (BSR) has been highly relative issue to stakeholders. In this paper we present a proposed framework for examining the relationship between Trust of BSR and firms performance. However, virtually few studies have attempted to regards the relationship between trust of BSR and firms performance, even if any they consider it in the perspective of consumers/ individuals. Hence this study intends to make new contribution to literature by proposed causal relationships between trust of BSR and firms performance in the perspective of organization.

Keywords: Business social responsibility (BSR), Trust of BSR, Firm performance, Nigeria.
\end{abstract}

\section{Introduction}

In recent years the issue of Business social responsibility (BSR) has become main tributary in USA and Europe, which offer maintain to creditable causes, and enhance business practices as well increase practical and build social impact on the community (David, 2012; Gorondutse \& Hilman, 2012).Similarly, Business Social Responsibility is getting an increasingly important issue for economic agents due to a new attention to all the aspects of firms activities and their relationship with stakeholders. Firms social activities are more than a simply way to achieve economic grades, since through these activities companies can develop good relationship with stakeholders (Freeman, 1984) and, indirectly, create value for shareholders. In fact, firms with the attitude toward disclosure related to social responsibility activities appear to be able to develop and maintain better relationship with stakeholders in general (Abiodun, 2012; Carroll \& Shabana, 2010; David, 2012).

Furthermore, there is an enormous deal of vagueness and improbability about what business social responsibility really means as well as what drives a business to practise it. Whereas business ethics and corporate governance join to create the means to attain organizational excellence, the valid examination is when this excellence is transformed into business sustainability and here, business social responsibility acting a major role, an assortment of views have been obtainable to give explanation the significance or else of business social responsibility in business action (Carroll, 1979; Detomasi, 2008; Friedman, 1970; Secchi, 2007).

The idea driving our study is that the creation of trust among stakeholders is one of the most immediate consequences of a company's social performance. Trust is a fundamental asset in every business and nonbusiness relationship. Indeed, the high level of abstraction of the construct is useful in interpreting many types of relationships (inter-personal, intra- and inter-organizational, social, business, etc.) that are studied from different perspectives (Ring \&Van de Ven, 1992, 1994, Zaheer \& Venkatraman 1995, Das \& Teng, 1998, 2001, Zaheer, McEvily, \& Perone, 1998). Trust is crucial for understanding business relationships when the one who trusts is in a vulnerable (high risk) position.

However, BSR become a mean to strengthen and reinforce the relationships between the firms and communities in which it operates, this direct to identify and explore the role of trust as a fundamental assets in determining the linkages between the business and its stakeholders, the practices of social responsibility is not a new in Nigeria but unfortunately, is mainly adhere by multinational corporations ( Abiodun, 2012;Adegbeti \& Chizu, 2011; Amaeshi, Adi, Ogbechie, Amao, 2006; Hassan, 2007; Ojo, 2007; Opara, 2010; Okoro, 2012; Okoye, 2009) to date there little or no empirical evidences to what might happens within the indigenous firms (local firms).Therefore, the main objective of this paper is to provide a proposed framework that will link Trust of BSR and firms performance, and will contribute in literature and facilitate the links outside Europe and USA especially Nigeria as developing country and emerging nation.

This paper will be organized as follows. Next, a discussion on the important concepts in business social responsibility and Trust of BSR is highlighted. Then, previous works that relate the concepts are presented toward the development of a model that explains the relationships. To link these relationships, stakeholder theory is used as a root. Hence, an elaboration of stakeholder theory is also offered.

\section{Business Social Responsibility (BSR)}

BSR is regarded as the moral obligations that maximize the positive influence of the firm on its social environments and minimize the negative influence as well (Carroll \& Shabana, 2010; Secci, 2007).Business 
Social Responsibility is a concept with a growing currency around the globe. It frequently overlaps with similar approaches such as business ethics, corporate sustainability, corporate sustainable development, Stakeholder management, and corporate responsibility (Detomasi, 2008; Lee, 2008; Matter \& Moon, 2008). Moreover, BSR has a wide range of potential meaning: it can be considered as the private sector's way of integrating the economic, social, and ecological imperatives of its activities (David, 2012).

The term business social responsibility has become an sunshade term which embraces both the descriptive and normative aspect of meadow, as well introduction an stress on all that firms are achieving the dominion of social responsibility policies, and results (Abiodun, 2012). Socially responsible of business practice refer that BSR is the social preparation where the business adapts and practices unrestricted business conducts and investments that sustain social causes to develop community well-being in order to defend the surroundings (Carroll \& Shabana, 2010; Detomasi, 2008; Secci, 2007).

Previous researches to date have found mixed results on the connecting relationships between BSR and corporate social performances (CFP) (Griffin, 2000; Pederson, 2006; Peloza \& Papania, 2008). Previous studies propose that being socially responsible usually enhance an organizational performance (Cochran \& Wood, 1984; Fang, Huang, \& Stephenie, 2010; Fombrun \& Shanley, 1990; Peloza \& Papania, 2008), however, further studies suggest that it does not (Margolis and Walsh 2003; Waddock \& Graves, 1997; Berrone, Suroca,\& Tribo, 2007). This inconsistency in results has received so many demands for taking account the diverse and country specific nature of stakeholder priorities and measures of financial performances. However, base on the previous research, studies that have examined BSR and local firms' performance are still lacking. To fill in this gap, this paper proposes to examine BSR dimensions as an antecedent of firm's performance.

\subsection{Trust of Business Social Responsibility (BSR)}

Trust literature offers a huge variety of constructs (Castaldo, 2002). Trust has been generally defined as 'an expectation that the trustee is willing to keep promises and to fulfil obligations'. The expectation is associated with such antecedents as the level of competencies, honesty and goodwill of the trustee, and also with her non opportunistic attitudes (Rotter, 1971). Trust is based on the expectation of ethically justifiable behaviour, firm involvement in BSR campaigns an ethically behaviour placing trust a moral value construct as central in evaluating the performance of BSR (Puusa, \& Tolvanen, 2006; Shamir \& Lapidot, 2003). In addition, Trust has been regarded as the social bond that can hold diverse type of organizational structures together (Atkinson \& Butcher, 2003; Puusa, \& Tolvanen, 2006; Tian, Wang, \& Yang, 2011). Trust is an important component in helpful human associations and archived an organizational goal. It provides togetherness and gives individuals an emotion of safety. (Puusa, \& Tolvanen, 2006; Pivato, Missani, \& Tencati, 2008). Puusa, \& Tolvanen, (2006) Shamir \& Lapidot (2003), suggest that trust can be an interpersonal and a collective event. Trust is view at three levels within an organization: group, system, and individual level.

In addition, while some scholars as Pivato et al., (2008) argue that Trust of BSR influences firm performances other scholar hold the opposite side of the argument. For example, Atkinson \& Butcher, (2003); Puusa, \& Tolvanen, (2006) observe that it's difficult to evaluate performances, but it is believe that Trust of BSR is an significant factor that among others influences the firm performance. Similarly, Tian et al., (2011) stress that there is ample evidences in the literature establishing the influences of Trust of BSR on firm performances.

However, based on the previous research results trust of BSR level in an organization has a direct effect on their performances (Ellen, Webb, \& Morh, 2006; Osterhus, 1997; \& Perrini, Castaldo, Misani, Tencati, 2010). Similarly, previous study use Trust of BSR on the customer perspectives, (Ellen et al., 2006; Osterhus, 1997; Tian et al., 2011) what make different from others is that this study will make a different contribution by using trust of BSR from organizational perspective.

\subsection{Firm Performance}

Financial performance considers one of the most important studied indicators of the strategic value of BSR (Orlitzky, Schmidt, \& Rynes, 2003). Previous studies have started the empirical study of BSR and financial performance (FP) over three decades ago in western countries. Many firms have faced the pressure for corporate accountability which it is increasing from their stakeholders (managers, employees, customer, government, shareholders, and so on) (Waddock 2004). This pressure includes some aspects such as lawful, community, moral, and financial aspects.

Mixed results have been produced by studies on the effects of BSR activities on firm value. Some studies have concluded beneficial effects while others found that the effects are negative or no relationship. For example, Margolis and Walsh's found that $4 \%$ of the 160 studies examined considered a negative relationship between BSR and financial performance, $55 \%$ a positive relationship, $22 \%$ was no association, and $18 \%$ reported a diverse relationship. Furthermore, Orlitzky et al. (2003) achieved another meta- meta-analysis and 
revealed related results. While other studies are not similarly stable concerning the relationship between CSR and short-run financial return (McWilliams \& Siegel 2000).

The examination of the nature of the relationship between measures the long-term financial performance and a measure of BSR is the second set that is used from accounting and financial measures of profitability (e.g. Aguilera, Ruth, Rupp, Williams, \& Ganapathi, 2007; McWilliams \& Siegel 2000; Simpson \& Kohers 2002; Waddock \& Graves, 1997). Accounting returns such as return on equity, or return on investment, return on assets are used to identify managers' discretionary allocations of funds to different projects and policy choices. As consequently, these measures reflect internal decision-making capabilities and managerial performance.

Given the debate over the proper measure of financial performance, in this study will consider both accounting- and stock-market-based measures to investigate the relationships between concurrently, previously, and subsequently measured firm performance and business social responsibility. The study will also enhance upon the methodology used in previous studies in order to evaluate business social responsibility from knowledgeable external sources.

\subsection{Proposed Research Framework}

Based on the abovementioned argument and literature review, this paper proposes a conceptual framework as illustrated in Figure 1.

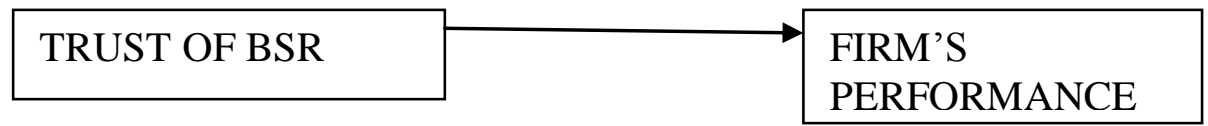

Figure 1: Proposed research framework

The proposed conceptual framework shows the relationship between trust of BSR and firms performance. Based on Figure 1, Trust of BSR as variable can determine the effectiveness of organisation performance. In this context the framework is bases on several assumptions. The framework state that an ability of firms performances depend on the trust of BSR. Therefore, the more trust of BSR the likely will affect the firms performance, as a result the proposed framework uses two constructs, trust of BSR and firms performance. And this framework integrates executive motives with stakeholder theory to argue that many managers develop social responsibility strategies based on the perceived stakeholder priorities (Jones, 1995).

\section{Conclusion}

This paper has proposed on the relationship between trust of BSR and firms performance as depicted in Figure 1. If the proposed framework is validated, the finding will provide a significant contribution to the literature and managers and practitioners in making better decisions, important insight to managers and practitioners into the significant role of trust of BSR on firm's performance in Nigeria.

\section{References}

[1] Abiodun, B. Y. (2012). The impact of corporate social responsibility on firms' profitability in Nigeria, European Journal of Economics, Finance and Administrative Sciences, issue 45, 39-50.

[2] Adegbite, E., \& Chizu, N. (2011) Corporate governance and Responsibility in Nigeria. International journal of Disclosure and Governance. 8 (3), 252-271.

Aguilera, R.., Ruth, V., Rupp, D., Williams, C., \& Ganapathi, J. (2007). Putting the S Back in Corporate Social Responsibility: A Multilevel Theory of Social Change in Organizations, Academy of Management Review, 32, 836-863.

[1] Amaeshi, K., Adi, B., Ogbechie, C. \& Amao, O. (2006). Corporate Social Responsibility in Nigeria: Western Mimicry or Indigenous influence? No 39-2006, ICCSR Research paper series-ISSN 1479-5124, The University Nottingham.

[2] Atkinson, S., \& Butcher, D. (2003). Trust in Managerial Relationships, Journal of Managerial Psychology, 18, $282-304$.

[3] Berrone, P., Surroca, J., Tribo, J. A., (2007), Corporate Ethical Identity as Determinant of Firm Performances: A Test of The Mediating Role of Stakeholder Satisfaction, Journal of Business Ethics, 76, 35-53.

[4] Castaldo, S. (2002). Meanings of trust: a Meta analysis of trust definitions. Paper presented at Second Euram Conference, Stockholm.

[5] Carroll, A. B., \& Shabana, K. M. (2010). The business case for corporate social responsibility: a review of concepts research and practices. International Journal of Management Review, 12 (1), 85-105.

[6] Carroll, A.B. (1979). A Three-dimensional conceptual model of corporate social performance. Research in corporate social performance and policy, 4 .

[7] Das, T.K., \& Teng, B.S. (1998). Between trust and control: developing confidence in partner cooperation in alliances, Academy of Management Review, 23(2), 491-513.

[8] Das, T.K., \& Teng, B.S. (2001). Trust, control, and risk in strategic alliances: an integrated framework. Organization Studies, 22(2), 251-283.

[9] David, O. A. (2012). An assessment of the impact of corporate social responsibility on Nigeria society: The examples of banking and communication industries. Universal Journal of Marketing and Business Research, 1(1), 017-043.

[10] Detomasi, D. A. (2008). The political roots of corporate social responsibility, Journal of Business Ethics, 82, 807-819.

[11] Friedman, M. (1970). The social responsibility of business is to increase its profit, New York Time Magazines (September 13). 
[12] Ellen, P. S., Webb D. J., \& Mohr, L. A., (2006), Building Corporate Associations: Consumer Attributions for Corporate Socially Responsible Programs,Academy of Marketing Science 34(2), 147-157.

[13] Fang, S., Huang, C., \& Stephanie, W. (2010). Corporate social responsibility strategies, dynamiccapability and organizational performance: Cases of top Taiwan- selected benchmark enterprises. African journal of Business Management. 4(1), 120-132.

[14] Gorondutse, A. H., \& Hilman, H. A. (2012). A conceptual relationships between business social responsibility (BSR) and firms performances in Nigeria. International Journal of arts and commerce, 1(4), 45-53.

[15] Griffi n , J . (2000). Corporate social performance: Research directions for the 21st century, Business \& Society, 39 (4), 479 - 491 .

[16] Hassan, A. (2007). Determinants of Corporate Social Performance disclosure in the Nigerian Food and Beverages Industry. Unpublished M.Sc Theses, Bayero University, Kano, Nigeria.

[17] Jones, T. M. (1995). Instrumental stakeholder theory: A synthesis of ethics and economics, Academy of Management Review, 20(2), 404-437.

[18] Lee, M. P. (2008). A review of the theories of corporate social responsibility: its evolutionary path and the road ahead. International journal of management reviews. 10 (1), 53-73.

[19] Matten, D., \& Moon, J. (2008). "Implicit" and "explicit" CSR: A conceptual framework for a comparative understanding of corporate social responsibility. Academy of Management Review, 33(2), 404-424.

[20] McWilliams, A., \& Siegel, D. (2000). Corporate social responsibility and financial performances: Correlation or Misspecification? Strategic Management Journal, 21(5), 603-609.

[21] Ojo, O. (2007). Appraisal of the practice of Social responsibility by business organizations in Nigeria covenant University, Ota, Nigeria.

[22] Okoro, E. (2012). Ethical And Social Responsibility In Global Marketing: An Evaluation of Corporate Commitment To Stakeholders. International Business \& Economics Research Journal. 11(8), 863-870.

[23] Okoye, A. (2009). Theorising corporate social responsibility as an essentially contested concept:is a definition necessary? Journal of Business Ethics, 89 (4), 613-627.

[24] Opara, O. J. (2010). Corporate Social Responsibility: An Analysis of pertinent Issues, Challenges\& Opportunities in Nigeria. Franklin Business \& Law journal, 4, 98-112.

[25] Orlitzky, M., Schmidt, F.L., \& Rynes, S. L. (2003). Corporate social and financial performance: A meta-analysis, Organizational Studies, 24(3), 403-441.

[26] Osterhus, T. L. (1997). Pro-social Consumer Influence Strategies: When and How Do They Work? Journal of Marketing, 61(4), 1629.

[27] Pederson, E. R. (2006) Making Corporate Social Responsibility (CSR) operable: How companies translate stakeholder dialogue into practice, Business and Society Review, 111 (2), $137-163$.

[28] Peloza, J. \& Papania, L. (2008). The Missing link Between Corporate SocialResponsibility and Financial Performances: Stakeholder Salience and Identification, Corporate Reputation Review, 11(20), 169-181.

[29] Perrini, F., Castaldo, S., Misani, N., \& Tencati, A., (2010). The Impact of Corporate Social Responsibility Associations on Trust in Organic Products Marketed byMainstream Retailers: A study of Italian Consumers. Business Strategyand the Environment, 19, 512526.

[30] Pivato, S., Misani N., \& Tencati A., (2008), The Impact of Corporate Social Responsibility on Consumer Trust: The Case of Organic Food, Business Ethics: A European Review 17(1), 3-12.

[31] Puusa, A., Tolvanen, U. (2006). Organization identity and trust. Journal of Business Ethics and Organization Studies. 11(2), $29-33$.

[32] Ring, P.S., \& Van de Ven, A.H. (1992). Structuring cooperative relationships between organizations. Strategic Management Journal, 13(7), 483-498.

[33] Rotter, J.B.(1971). Generalized expectancies for interpersonal trust. American Psychologist, 26, 443-452.

[34] Secchi, D. (2007). Utilitarian, managerial and relational theories of corporate social responsibility, International Journal of Management Reviews, 9(4), 347-373.

[35] Tian, Z., Wang, R., \& Yang, W., (2011). Consumer Responses to Social Responsibility(CSR) in China, Journal of Business Ethics, $101,197-212$.

[36] Shamir, B., \& Lapidot, Y. (2003). Trust in Organizational Superiors: Systemic andCollective Considerations, Organization Studies, 24, 463-491.

[37] Waddock, S.A. \& Graves, S.B. (1997). The corporate social performance-financial performance link. Strategic Management Journal, 18(4), 303-319.

[38] Zaheer, A., \& Venkatraman, N. (1995). Relational governance as an inter organizational strategy: an empirical test of the role of trust in economic exchange. Strategic Management Journal, 16, 373-392.

[39] Zaheer, A., McEvily, B. \& Perrone, V. (1998). Does trust matter? Exploring the effects of interorganizational and interpersonal trust and performance. Organization Science, 9(2), 141-159. 